\title{
Effect of Wood Compost on Extreme Soil Characteristics in the Lusatian Lignite Region
}

\author{
Wael Nada ${ }^{1}$, Oswald Blumenstein ${ }^{1}$, Sarina Claassens ${ }^{2 *}$, Leon van Rensburg ${ }^{2}$ \\ ${ }^{1}$ Institute of Earth and Environmental Sciences, Potsdam University, Potsdam, Germany; ${ }^{2}$ Unit for Environmental Sciences and \\ Management, North-West University, Potchefstroom, South Africa. \\ Email: "sarina.claassens@nwu.ac.za
}

Received October $23^{\text {rd }}, 2012$; revised November $25^{\text {th }}, 2012$; accepted December $6^{\text {th }}, 2012$

\begin{abstract}
Open-cast lignite mining operations result in a loss of soil quality. Soils associated with coal mining are usually characterised by poor physical and chemical parameters. Low $\mathrm{pH}$ and heavy metal toxicity are of the main concerns. The lignite and pyrite content of the dump materials of the Lusatian open-cast mining district in Eastern Germany resulted in high acidification potential and low organic matter content of soils. These extreme conditions require considerable amounts of alkaline materials like compost to enable revegetation. This study was carried out to evaluate the effect of different application rates of wood compost on soil physico-chemical properties in two representative soil substrates (Tertiary and Quaternary) and on some plant growth parameters. Soil in each site was mixed with wood compost and sown with a grass mixture. The data of both studied soils showed an improvement in physical properties such as water holding capacity and bulk density in soil ameliorated with compost. Most soil chemical properties were increased significantly with the increase of compost application rates, particularly organic matter content, total nitrogen and cation exchange capacity. Compared to the control treatment in each site, the treated soil with compost showed a significant increase in grass biomass (fresh and dry matter yield). The results of these experiments revealed that addition of wood compost had significant positive effects on the soil physical and chemical properties, which affected the response of plant growth and can facilitate the revegetation of substrates contaminated with coal spoil.
\end{abstract}

Keywords: Coal Spoil; Mining; Reclamation; Revegetation

\section{Introduction}

Open-cast lignite (brown coal) mining operations in the Lusatian district in eastern Germany had disastrous environmental effects and resulted in devastation of soil by creating an area of almost $1000 \mathrm{~km}^{2}$ covered by spoil heaps of clastic overburden sediments of Tertiary and Quaternary age [1]. These spoil heap sediments often abound in lignitic components in the form of coal fragments or as coal dust. Due to the high acidification potential of the substrates and their intensive weathering dynamics, especially in the initial phase, it is hard to predict what possible equilibrium state these developing mining ecosystems are approaching. The extreme acid soil reaction impedes the success of mine soil reclamation and revegetation practices because it is difficult to initiate plant growth in these soils [2]. Unless revegetation of these areas can be achieved, the goal of re-establishing agricultural and forest ecosystems will not be achieved.

While current knowledge of the physical and chemical

"Corresponding author. processes in the dumping substrates are limited, it is known that the Quaternary sediments in this area are relatively low in their lignite and pyrite content and have a higher potential for successful revegetation than the Tertiary sediments [3]. In addition to fertilisation of the soil, the addition of compost and/or sewage sludge should also be considered during treatment [4]. For successful reclamation, high application rates of basic materials are required to neutralise soil acidity and hence create the potential for plant growth. The addition of organic material will aid in the improvement of soil structure [5] and consequently also prevent leaching of added fertilisers that result due to the sandy texture of the spoil substrates. The addition of compost for the improvement of the soil structure will mainly result through a reduction in bulk density (BD) and increases in porosity, aeration, water holding capacity (WHC), buffer capacity and cation exchange capacity (CEC). The addition of compost with a significant amount of humified organic matter, leads to longer lasting effects of this organic matter in the soil, increasing soil quality. Polysaccharides and other polymeric substances present in organic matter act as aggre- 
gating compounds [6] and increase micro-pores in the soil. A study [7] on the effect of composted yard waste on the movement of water in a sandy soil, found that water retention in the soil was increased. It has also been reported that soil total carbon $(\mathrm{C})$, nitrogen $(\mathrm{N})$ and phosphorus $(\mathrm{P})$ were increased markedly with increasing compost application rate [8] and that soil physical properties of ameliorated soils are generally improved $[9,10]$.

Reclamation or rehabilitation from the mining industry perspective aims to achieve the return of a disturbed site to a degree of its former state or to a sustainable usable condition, it emphasises the reparation of ecosystem processes, productivity and services [11]. The success of reclamation depends on whether the rehabilitation measures applied will be sustainable, in the long term, under normal land management. An understanding of the response of vegetation to ecosystems affected by mining and the effect of amelioration is of critical importance to facilitate the reclamation of such areas. The aim of this study was therefore to evaluate the effect of different compost treatments on some of the soil physical and chemical properties of Tertiary and Quaternary sand contaminated with coal spoil and on vegetation growing at these sites.

\section{Materials and Methods}

\subsection{Study Area}

The investigation was conducted at two sites located in the Lusatian mining region. The first location was typified by Tertiary sand located on Bergen grazing land (TM 25: Sheet 4551, Hoyerswerda town, Gauss-Krueger coordinates $\mathrm{R}=5,447,250 \mathrm{~m}, \mathrm{H}=5,706,900 \mathrm{~m}$ ). The second location was typified by Quaternary sand located on the prospective area along the banks and shores of Neuwieser lake (TM 25: Sheet 4550, Lauta town, $10 \mathrm{~km}$ west of Hoyerswerda, Gauss-Krueger coordinates $\mathrm{R}=5$, $436,500 \mathrm{~m}, \mathrm{H}=5,704,750 \mathrm{~m}$ ).

\subsection{Experimental Design}

The compost used in this investigation was produced from mixing woodchips from Quercus rubra with lake mud as a nitrogen source and composting for three months in a greenhouse. At the end of the composting period, wood compost treatments were air dried, sieved and mixed before it was added to the soil in both locations to a depth of $50 \mathrm{~cm}$. Soil was taken from the plots at each location, mixed with wood compost and then returned to the plots after each plot was lined with plastic. The size of each plot was $2 \times 1 \mathrm{~m}$ and the distance between plots $30 \mathrm{~cm}$. The different soil treatments were applied in a completely randomised design. Compost was added to the Tertiary soil at the following rates: $0.0 \%$ (T1), $3.0 \%$ (T2), 5.0\% (T3) and 10.0\% (T4). Quaternary soil re- ceived rates of $0.0 \%(\mathrm{Q} 1), 1.5 \%(\mathrm{Q} 2), 3.0 \%(\mathrm{Q} 3)$ and $5.0 \%(\mathrm{Q} 4)$ compost.

Each treatment was vegetated with the RSM 7.2.1 grass seed mixture (Deutsche Rasengesellschaft e.V. (DRG), Bonn, Germany). The mixture consisted of $45 \%$ Festuca ovina duriuscula, 10\% Festuca rubra commutata, 15\% Festuca rubra rubra, 15\% Festuca rubra trichophylla and $15 \%$ Lolium perenne. This is the same grass seed mixture that was used as part of the closure plan of the company (Lausitzer und Mitteldeutsche BergbauVerwaltungsgesellschaft $\mathrm{mbH}$ ). It is the standard mixture for sowing in dry regions and the optimum sowing quantity is $20 \mathrm{~g} \cdot \mathrm{m}^{-2}$. Experimental plots were not irrigated.

The experimental plots were monitored for six months and ended with the end of the growing season for grass. At the end of the experimental period, soil samples from each treatment at both locations were air dried, crushed and sieved through a $2 \mathrm{~mm}$ sieve before analysis.

\subsection{Soil and Vegetation Properties}

All analyses were conducted in triplicate. Physical and chemical analyses of soil samples before and after treatment with compost were conducted according to standard procedures. The $\mathrm{pH}$ value was measured in a soil suspension with $0.01 \mathrm{M} \mathrm{CaCl}_{2}(1: 5 \mathrm{w} / \mathrm{v})$ after shaking for 30 $\min$ [12]. Electrical conductivity $\left(\mathrm{EC}, \mathrm{dS} \cdot \mathrm{m}^{-1}\right)$ was measured in the soil extraction solution of 1:5 w/v (soil: distilled water) [13]. Organic matter (OM) content (\%) was determined by weight loss on ignition at $550^{\circ} \mathrm{C}$ [14]. Cation exchange capacity (CEC) was determined using the $\mathrm{BaCl}_{2}$ method [15]. The percentages of total carbon (TC) and total nitrogen (TN) were determined using a CHN analyser according to the method of Tabatabai and Bremner [16]. Water holding capacity (WHC) [17], dry bulk density (BD) [18] and dry particle density (PD) [19] were also determined. Soil particle distribution of the studied soil was determined according to the methods described by Day [20].

At the end of experiment, height $(\mathrm{cm})$, percentage cover, fresh matter yield (FMY) and dry matter yield (DMY) $\left(\mathrm{g} \cdot \mathrm{m}^{-2}\right)$ of the grasses were determined. The aboveground biomass of the grass was removed and weighed to determine FMY. For DMY determinations, aboveground biomass was air dried and then oven dried at $70^{\circ} \mathrm{C}$ for 48 hours before weighing.

\subsection{Statistical Analysis}

The data obtained was statistically analysed using analysis of variance (ANOVA). The treatment means were compared using the Least Significant Difference (LSD) range test at a 5\% level of probability [21]. Correlation coefficient analysis was also carried out on the data to investigate the relationship between compost application 
rates and plant growth parameters. All statistical analyses were performed with the COSTAT software package (Version 6.311, Monterey, CA, USA).

\section{Results and Discussion}

Physical and chemical properties of Tertiary sand, Quaternary sand and compost before treatment are presented in Table 1. There was a clear difference between the physical and chemical properties of the two sand substrates when compared to each other and to the compost before treatment of the sites, with the compost containing higher amounts of OM, TC and TN. The compost also had a higher $\mathrm{pH}, \mathrm{EC}$ and $\mathrm{CEC}$ and lower $\mathrm{BD}$ than the Tertiary and Quaternary sands.

The results for the physical and chemical characterisation of the Tertiary and Quaternary substrates after treatment with wood compost are presented in Table 2. Different application rates of compost produced effects on the soil physical and chemical properties that were statistically significant $(p<0.05)$ in some cases, but not in every instance.

The physical and chemical properties that characterised the compost had an influence on the Tertiary and Quaternary substrates when applied in different ratios. The results showed no significant differences $(p<0.05)$ between application rates of $0.0 \%$ (T1) and 3.0\% (T2) for dry BD or PD, while significant differences were recorded with the application of 5.0\% (T3) and 10.0\% (T4) compost. As the rate of applied compost increased, the $\mathrm{BD}$ and PD decreased. The same trend was observed for Quaternary sand.

The observations could be explained by the improvement in soil aggregation and structure due to the addition of composted organic matter which will lead to a reduced potential for soil compaction [9,10]. In addition, compost increases soil porosity due to the creation of larger particles with larger air spaces in between as well as an increase in the amount of rounded pores [22]. Increases in the WHC, EC, $\mathrm{pH}, \mathrm{OM}, \mathrm{CEC}, \mathrm{TC}$ and TN were also consistent with an increase in the compost application rate. Statistically significant differences were observed between some of the treatments (Table 2), especially with compost application rates of $5.0 \%$ and $10.0 \%$ in the Tertiary sand and 3.0\% and 5.0\% in the Quaternary sand. The increase in OM in sites treated with compost resulted in the increases in the other soil chemical properties. These findings are consistent with other studies that suggest that the addition of compost in sandy soils can facilitate moisture dispersion by allowing water to more readily move laterally from its point of application [6].

Table 1. Some chemical and physical properties of the studied soils and wood compost.

\begin{tabular}{cccccccccccc}
\hline & $\mathbf{p H}$ & $\mathbf{E C ~ d S} \cdot \mathrm{m}^{-1}$ & $\mathbf{O M} \%$ & $\mathbf{C E C ~} \mathrm{cmol}(+) \mathrm{kg}^{-1}$ & $\mathbf{T C ~} \mathrm{g} \cdot \mathrm{kg}^{-1}$ & $\mathbf{T N ~} \mathrm{g} \cdot \mathrm{kg}^{-1}$ & $\mathbf{~ B D ~} \mathrm{g} \cdot \mathrm{m}^{-3}$ & Sand \% & Silt \% & Clay \% & Gravel \% \\
\hline $\mathbf{T}$ & 3.6 & 0.19 & 2.4 & 3.4 & 12.3 & 0.4 & 1.3 & 90.0 & 5.8 & 1.2 & 3.0 \\
$\mathbf{Q}$ & 4.0 & 0.07 & 0.8 & 3.1 & 4.7 & 0.2 & 1.5 & 92.0 & 1.8 & 0.2 & 6.0 \\
$\mathbf{C}$ & 7.6 & 4.26 & 36.7 & 46.4 & 29.4 & 1.8 & 0.5 & $\mathrm{ND}$ & $\mathrm{ND}$ & $\mathrm{ND}$ & $\mathrm{ND}$ \\
\hline
\end{tabular}

$\mathrm{T}=$ tertiary sand, $\mathrm{Q}=$ quaternary sand, $\mathrm{C}=$ compost, $\mathrm{ND}=$ not determined.

Table 2. Effect of wood compost treatment on soil physical and chemical properties of Tertiary (T) and Quaternary (Q) substrates.

\begin{tabular}{|c|c|c|c|c|c|c|c|c|c|}
\hline Treatments & BD $\mathrm{g} \cdot \mathrm{cm}^{-3}$ & PD $\mathrm{g} \cdot \mathrm{cm}^{-3}$ & WHC \% & $\mathbf{E C ~ d S} \cdot \mathrm{m}^{-1}$ & $\mathbf{p H}$ & OM \% & CEC $\mathrm{cmol}^{\prime} \cdot \mathrm{kg}^{-1}$ & TC \% & TN \% \\
\hline \multicolumn{10}{|c|}{ Tertiary sand } \\
\hline T1 & $1.33 \mathrm{a}$ & $2.39 \mathrm{a}$ & $30.85 \mathrm{c}$ & $0.23 \mathrm{c}$ & $3.62 \mathrm{~d}$ & $2.48 \mathrm{c}$ & $3.46 \mathrm{c}$ & $1.20 \mathrm{c}$ & $0.03 \mathrm{~b}$ \\
\hline $\mathbf{T} 2$ & $1.32 \mathrm{a}$ & $2.37 \mathrm{a}$ & $32.43 \mathrm{c}$ & $0.24 \mathrm{c}$ & $3.86 \mathrm{c}$ & $2.81 \mathrm{c}$ & $4.17 \mathrm{~b}$ & $1.25 \mathrm{c}$ & $0.04 \mathrm{~b}$ \\
\hline T3 & $1.25 \mathrm{~b}$ & $2.28 \mathrm{~b}$ & $35.87 \mathrm{~b}$ & $0.27 \mathrm{~b}$ & $3.95 \mathrm{~b}$ & $3.28 \mathrm{~b}$ & $4.35 \mathrm{~b}$ & $1.37 \mathrm{~b}$ & $0.04 \mathrm{~b}$ \\
\hline T4 & $1.19 \mathrm{c}$ & $2.24 \mathrm{c}$ & $47.92 \mathrm{a}$ & $0.36 \mathrm{a}$ & $5.30 \mathrm{a}$ & $4.34 \mathrm{a}$ & $7.97 \mathrm{a}$ & $1.68 \mathrm{a}$ & $0.07 \mathrm{a}$ \\
\hline $\mathbf{L S D}_{0.05}$ & 0.03 & 0.03 & 2.9 & 0.02 & 0.2 & 0.44 & 0.31 & 0.07 & 0.02 \\
\hline \multicolumn{10}{|c|}{ Quaternary sand } \\
\hline Q1 & $1.57 \mathrm{a}$ & $2.45 \mathrm{a}$ & $29.67 \mathrm{c}$ & $0.06 \mathrm{c}$ & $3.96 \mathrm{c}$ & $0.80 \mathrm{c}$ & $3.12 \mathrm{c}$ & $0.41 \mathrm{c}$ & $0.01 \mathrm{c}$ \\
\hline Q2 & $1.55 \mathrm{a}$ & $2.43 \mathrm{a}$ & $32.40 \mathrm{~b}$ & $0.08 \mathrm{c}$ & $4.25 \mathrm{c}$ & $0.90 \mathrm{c}$ & $3.18 \mathrm{c}$ & $0.44 \mathrm{c}$ & $0.02 \mathrm{~b}$ \\
\hline Q3 & $1.51 \mathrm{~b}$ & $2.39 \mathrm{~b}$ & $32.28 \mathrm{~b}$ & $0.12 \mathrm{~b}$ & $5.17 \mathrm{~b}$ & $1.24 \mathrm{~b}$ & $3.95 \mathrm{~b}$ & $0.49 \mathrm{~b}$ & $0.02 \mathrm{~b}$ \\
\hline Q4 & $1.45 \mathrm{c}$ & $2.30 \mathrm{c}$ & $36.37 \mathrm{a}$ & $0.17 \mathrm{a}$ & $5.75 \mathrm{a}$ & $1.54 \mathrm{a}$ & $4.13 \mathrm{a}$ & $0.75 \mathrm{a}$ & $0.03 \mathrm{a}$ \\
\hline $\mathbf{L S D}_{0.05}$ & 0.03 & 0.03 & 0.53 & 0.03 & 0.32 & 0.12 & 0.15 & 0.04 & 0.01 \\
\hline
\end{tabular}

Mean of the same category followed by different letters are significantly different $(\mathrm{p}=0.05)$. 
Compost organic substances can hold up to 20 times its weight in water, which leads to increased WHC. It has been reported that an increase of $0.1 \%$ in the organic carbon content of soil leads to an increase of $0.4-0.6$ mass percent in WHC [9].

Data presented in Table 2 demonstrated that the application of wood compost led to a significant increase in soil $\mathrm{pH}$ in both Tertiary and Quaternary sand. The highest $\mathrm{pH}$ values were consistent with the highest application rate of compost in both substrates. The increase in $\mathrm{pH}$ is the result of the capacity of the compost to absorb free protons in the amended soil due to a high base content [23]. Moreover, organic fertilisation increases soil $\mathrm{pH}$ by forming alkaline humates during the process of decomposition and by aluminium complexing through organic molecules, such as fulvic acid and other low molecular weight acids [24,25]. Thus, an increase in $\mathrm{pH}$ is clearly valuable in these spoil contaminated substrates to ensure the improvement of micro-element availability and a reduction in the availability of elements that may be toxic to vegetation [26-28].

The effect of different application rates of wood compost on FMY and DMY of aboveground biomass is presented in Figure 1. The results showed that the grass responded positively to the application of wood compost, with an increase in FMY and DMY that was consistent
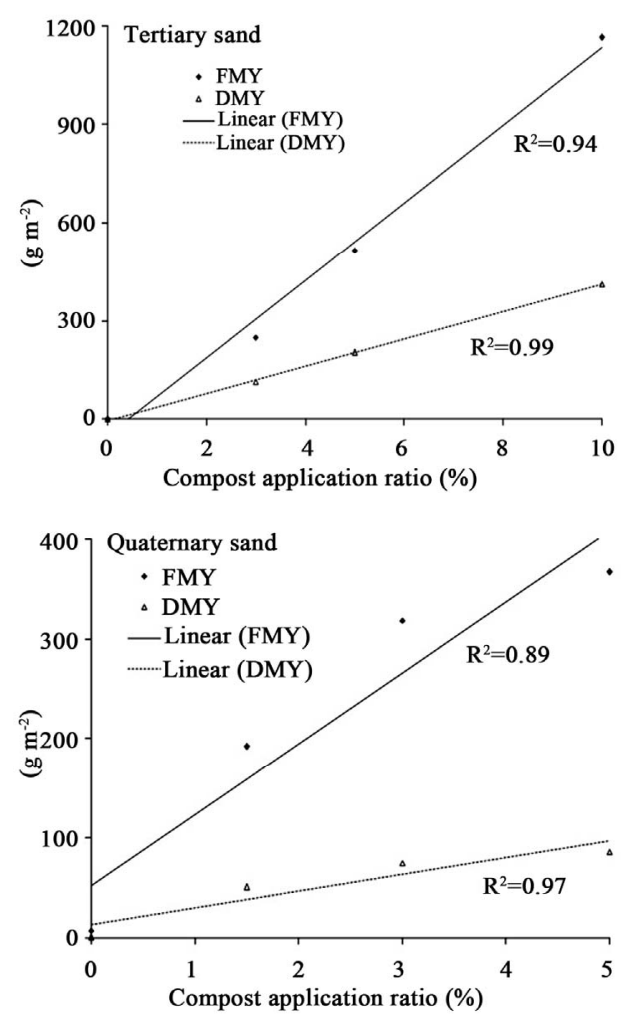

Figure 1. Relationships between the rate of applied compost, FMY and DMY of aerial part for the sown grass in Tertiary and Quaternary sand. with an increased application rate of the compost in both types of substrates. Generally, the FMY of RSM 7.2.1 grass in the Tertiary substrate was higher than in the Quaternary substrate. Higher amounts of OM, TN, CEC, WHC and proportion of fine particles in Tertiary sand could also have contributed to a better vegetation response. In both substrates, increased application rates of wood compost resulted in significant $(p<0.05)$ increases in the FMY and DMY of the grass. The T4 treatment had the highest FMY $\left(1165.4 \mathrm{~g} \cdot \mathrm{m}^{-2}\right)$ and DMY $\left(412.8 \mathrm{~g} \cdot \mathrm{m}^{-2}\right)$, while the lowest values were observed for T1 (FMY 0.4 $\mathrm{g} \cdot \mathrm{m}^{-2}$ and DMY $\left.0.2 \mathrm{~g} \cdot \mathrm{m}^{-2}\right)$. In the Quaternary substrates, the highest FMY $\left(366.8 \mathrm{~g} \cdot \mathrm{m}^{-2}\right)$ and DMY $\left(86.6 \mathrm{~g} \cdot \mathrm{m}^{-2}\right)$ was observed for Q4 and the lowest FMY $\left(7.8 \mathrm{~g} \cdot \mathrm{m}^{-2}\right)$ and DMY $\left(1.0 \mathrm{~g} \cdot \mathrm{m}^{-2}\right)$ for Q1.

The relationship between compost application rates and FMY and DMY (Figure 1) was determined with regression analysis and showed a significant and positive correlation. The best fit for the data was obtained with the linear regression model. Furthermore, it is evident that the FMY was higher than DMY. Compost enhances soil physical and chemical properties as well as microbial life in soil and correspondingly leads to improved vegetation growth $[23,29,30]$.

The relationships between the application rate of the compost and the fresh and dry matter yield for grass grown in the Tertiary and Quaternary substrates after treatment with wood compost are presented in Figure 2. The increased application of wood compost increased the height and covering percentage of the grass in the Tertiary and Quaternary substrates. Grass in the Tertiary sand showed the highest height and covering values. Generally, addition of wood compost resulted in an increase in grass height and emergence density and subsequent covering percentage was also positively influenced. The treatments that contained the highest amount of compost resulted in the highest covering percentage in both substrates.

\section{Conclusions}

The results of these field experiments indicate that incorporation of wood compost into Tertiary and Quarternary substrates contaminated with coal spoil enhanced the growth of vegetation. This can be ascribed to the positive influence of the compost on several soil physical and chemical properties, including $\mathrm{WHC}, \mathrm{EC}, \mathrm{pH}, \mathrm{OM}$, $\mathrm{CEC}, \mathrm{TC}$ and TN. On the other hand, $\mathrm{BD}$ and $\mathrm{PD}$ values of soil were decreased with increasing compost levels.

In both the studied substrates, plots treated with wood compost showed increases in fresh and dry matter yield, height and covering percentage of the grass when compared with untreated plots. In this context, wood compost proved to be an effective soil amendment to aid revegetation of coal mine waste. 



Figure 2. The height and covering percentage of the sowed grass in Tertiary and Quaternary sand as a function of compost application rates.

\section{Acknowledgements}

The authors gratefully acknowledge the support given by the Arbeitsgemeinschaft industrieller Forschungsvereinigungen (AIF) Berlin who funded the study.

\section{REFERENCES}

[1] R. F. Huettl and E. Weber, "Forest Ecosystem Development in Postmining Landscapes: A Case Study of the Lusatian Lignite District," Naturwissenschaften, Vol. 88, No. 8, 2001, pp. 322-329. doi:10.1007/s001140100241

[2] Z. Wang, Q. J. Wu, L. Wu, C. J. Ritsema, L. W. Dekker and J. Feyen, "Effects of Water Repellency on Infiltration Rate and Flow Instability," Journal of Hydrology, Vol. 231-232, 2000, pp. 265-276. doi:10.1016/S0022-1694(00)00200-6

[3] W. Schaaf, M. Gast, R. Wilden, J. Scherzer, R. Blechschmidt and R. F. Huettl, "Temporal and Spatial Development of Soil Solution Chemistry and Element Budgets in Different Mine Soils of the Lusatian Lignite Mining Area," Plant and Soil, Vol. 213, No. 1-2, 1999, pp. 169179. doi:10.1023/A:1004542205087

[4] R. Wilden, W. Schaaf and R. F. Huettl, "Element Budgets of Two Afforested Mine Sites after Application of Fertilizer and Organic Residues," Ecological Engineering, Vol. 17, No. 2-3, 2001, pp. 253-273. doi:10.1016/S0925-8574(00)00143-9
[5] D. Lynch, R. Voroney and P. Warman, "Soil Physical Properties and Organic Matter Fractions under Forages Receiving Composts, Manure or Fertilizer," Compost Science and Utilization, Vol. 13, No. 4, 2005, pp. 252-261.

[6] G. Masciandaro, B. Ceccanti, V. Ronchi and C. Bauer, "Kinetic Parameters of Dehydrogenase in the Assessment of the Response of Soil to Vermicompost and Inorganic Fertilizers," Biology and Fertility of Soils, Vol. 32, No. 6, 2000, pp. 479-483. doi:10.1007/s003740000280

[7] C. Pandey and S. Shukla, "Effects of Composted Yard Waste on Water Movement in Sandy Soil," Compost Science and Utilization, Vol. 14, No. 4, 2006, pp. 252-259.

[8] T. Speir, J. Horswell, A. Schaik, R. McLaren and G. Fietje, "Composted Biosolids Enhance Fertility of a Sandy Loam Soil under Dairy Pasture," Biology and Fertility of Soils, Vol. 40, No. 5, 2004, pp. 349-358. doi:10.1007/s00374-004-0787-6

[9] S. M. Aggelides and P. A. Londra, "Effect of Compost Produced from Town Wastes and Sewage Sludge on the Physical Properties of a Loamy and a Clay Soil," Bioresource Technology, Vol. 71, No. 3, 2000, pp. 253-259. doi:10.1016/S0960-8524(99)00074-7

[10] S. A. Wanas and W. Omran, "Advantages of Applying Various Compost Types to Different Layers of Sandy Soil: 1-Hydro-Physical Properties," Journal of Applied Sciences Research, Vol. 2, No. 12, 2006, pp. 1298-1303.

[11] SER, Society for Ecological Restoration International Science and Policy Working Group, "The SER Primer on Ecological Restoration," 2004. http://www.ser.org/

[12] DIN ISO 10390, "Soil Quality, Determination of pH," 2002.

[13] DIN ISO 1126, "Soil Quality, Determination of the Specific Electrical Conductivity," 1997.

[14] DIN 19684-3, "Methods of Soil Investigations for Agricultural Water Engineering-Chemical Laboratory Tests, Part 3: Determination of the Loss on Ignition and the Residue of Soil after Ignition," 2000.

[15] W. H. Hendershot and M. Duquette, "A Simple Barium Chloride Method for Determining Cation Exchange Capacity and Exchangeable Cations," Soil Science Society of America Journal, Vol. 50, No. 3, 1986, pp. 605-608. doi:10.2136/sssaj1986.03615995005000030013x

[16] M. A. Tabatabai and J. M. Bremner, "Automated Instruments for Determination of Total Carbon, Nitrogen, and Sulfur in Soils by Combustion Techniques," In: K. A. Smith, Ed., Soil Analysis Modem Instrumental Techniques, 2nd Edition, Marcel Dekker, Inc., New York, 1991, pp. 261-286.

[17] J. Dewis and F. Freites, "Physical and Chemical Methods of Soil and Water Analysis," Soil Bulletin, No. 10, FAO, Rome, 1970.

[18] G. R. Blake, "Bulk Density," In: C. A. Black, Ed., Methods of Soil Analysis, Part 1: Physical Properties, American Soil Association, Madison, 1965, pp. 374-390.

[19] G. R. Blake and K. H. Hartage, "Particle Density," In: A. Klute, Ed., Methods of Soil Analysis, Part 1: Physical Properties, American Soil Association, Madison, 1986, 
pp. $377-381$.

[20] P. R. Day, "Particle Fractionation and Particle-Size Analysis," In: C. A. Black, Ed., Methods of Soil Analysis, Part 1: Physical Properties, American Soil Association, Madison, 1965, pp. 545-567.

[21] G. W. Snedecor and W. G. Cochran, "Statistical Methods," 8th Edition, Iowa State University Press, Iowa, 1989.

[22] A. Rasool, T. G. Mousa and D. T. Rahim, "Influence of Vermicompost on Soil Chemical and Physical Properties in a Tomato (Lycopersicum esculentum) Field," African Journal of Biotechnology, Vol. 7, No. 14, 2008, pp. 23972401. doi: $10.1007 / \mathrm{s} 003740000335$

[23] D. Cox, D. Bezdicek and M. Fauci, "Effects of Compost, Coal Ash, and Straw Amendments on Restoring the Quality of Eroded Palouse Soil," Biology and Fertility of Soils, Vol. 33, No. 5, 2001, pp. 365-372.

[24] N. Q. Arancon, C. A. Edwards, R. Atiyeh and J. D. Metzger, "Effects of Vermicomposts Produced from Food Waste on the Growth and Yields of Greenhouse Peppers," Bioresource Technology, Vol. 93, No. 2, 2004, pp. 139144. doi:10.1016/j.biortech.2003.10.015

[25] Y. Renato, E. F. Manoel, C. P. D. Mara and C. B. José, "Organic Matter Fractions and Soil Fertility under the Influence of Liming, Vermicompost and Cattle Manure," Scientia Agricola, Vol. 60, No. 3, 2003, pp. 549-557.
doi:10.1590/S0103-90162003000300021

[26] X. F. Xian and G. I. Shokohifard, "Effect of pH on Chemical Forms and Plant Availability of Cadmium, Zinc, and Lead in Polluted Soils," Water, Air and Soil Pollution, Vol. 45, 1989, pp. 265-273. doi:10.1007/BF00283457

[27] F. Zeng, S. Ali, H. Zhang, Y. Ouyang, B. Qiu, F. Wu and G. Zhang, "The Influence of $\mathrm{pH}$ and Organic Matter Content in Paddy Soil on Heavy Metal Availability and Their Uptake by Rice Plants," Environmental Pollution, Vol. 159, No. 1, 2011, pp. 84-91. doi:10.1016/j.envpol.2010.09.019

[28] I. Muhammad, M. Puschenreiter and W. W. Wenzel, "Cadmium and $\mathrm{Zn}$ Availability as Affected by $\mathrm{pH}$ Manipulation and Its Assessment by Soil Extraction, DGT and Indicator Plants," Science of the Total Environment, Vol. 416, 2012, pp. 490-500. doi:10.1016/j.scitotenv.2011.11.029

[29] I. K. Maria, "Biowaste and Vegetable Waste Compost Application to Agriculture," Ph.D. Thesis, Cranfield University, Bedford, 2008.

[30] S. Suthar, "Impact of Vermicompost and Composted Farmyard Manure on Growth and Yield of Garlic (Allium stivum L.) Field Crop," International Journal of Plant Production, Vol. 3, No. 1, 2009, pp. 27-38. 